\title{
“DADDY, CAN'T YOU SEE WE ARE BURNING?" TRAUMATIC TIME AND PARENTAL RESPONSIBILITY IN KENNETH LONERGAN'S MANCHESTER BY THE SEA
}

Keywords: film; trauma; flashback; survival; responsibility.

Abstract: In Kenneth Lonergan's film Manchester by the Sea, screened in 2016, Lee commits a life-changing mistake: on his way to the mini-market, he forgets to put the screen on the fireplace. Upon his return, he becomes a numbed witness to the spectacle of his own family tragedy as the authorities remove his children's bodies from the burning house scene. This significant event is represented through a sequence of flashbacks, which designates said cinematic device as one of the film's most important features. Indeed, in The Trauma Question, Roger Luckhurst approaches the flashback as "the cinema's rendition of the frozen moment of the traumatic impact . . . flash[ing] back insistently in the present because the image cannot yet or perhaps ever be narrativized as past." Years after the incident, and still unable to address the wound of his parental negligence and child-death trauma, Lee dreams of his dead daughter suggestively asking, "Daddy, can't you see we are burning?" The question echoes the one from Freud's The Interpretation of Dreams, where another father dreams of his dead child being burnt. In Unclaimed Experience: Trauma, Narrative, and History, Cathy Caruth examines Freud and Lacan's analysis of this question as to the significance of grief articulation, trauma coping and trauma persistence in sleep and awaken reality. The purpose of this article is to examine anachrony as a feature which exalts the dysfunctional inertia of a present life and of a traumatized mind afflicted by events which have been impossible to either register, integrate or narrate. Secondly, the article will try to unearth the mechanics of Lee's grief and guilt via his daughter's question. Emphasis will be placed on Lee's inability to assume what Caruth calls the "ethical burden of survival" when asked to be his orphaned nephew's guardian. This will be viewed as a reminder of Lee's failure as a parent and as a challenge and invitation for the character to recover from the vacuum of his current death-in-life.

Kenneth Lonergan's critically acclaimed and Academy Award-winning film Manchester by the Sea revolves around Lee's hard to heal wound: his children's demise by burning due to his own, parental negligence. ${ }^{1}$ The drama, screened in 2016 ,

\footnotetext{
* Aristotle University of Thessaloniki; Greece; The University of New York, Prague; Czech Republic

${ }^{1}$ The film was listed as the top film of 2016 by the National Board of Review. At the $89^{\text {th }}$ Academy Awards and at the BAFTA Awards 2016, it won in the categories of Best Original Screenplay for Lonergan and Best Actor for Affleck. It was also Oscar-nominated for Best Picture, Best Director, Best Supporting Actress (Williams), and Best Supporting Actor (Hedges). Affleck also won the Golden Globe for his performance.
} 
Trauma, Narrative and Responsibility

opens with a flashback. With suggestive, choir singing forming the musical background, the objective camera initially captures the autumnal coastal scenery of the Manchester by the sea area from what appears to be the inside of a boat. Soon after, the cinematic lens switches to -and keeps its focus on- Claudia Marie, on which a little boy and two adult men, played by Casey Affleck and Kyle Chandler, are happily sailing. Amid chasing around and joking, one of the two men, Lee, asks the little boy, Patrick, a notable question: if he were to live on a desert island, whom would he choose to live with? His dad or his uncle, Lee? The boy answers "my dad," a pungent irony hiding behind this preference, as it will be later revealed. After this initial scene and after an indefinite time lapse, the narrative cuts to an almost deadly, wintry landscape with Lee engaged in the impossible task of cleaning a yard from the piled-up snow. The spectator then attests to Lee's idle and lonely life of a janitor who gets in trouble with strangers at bars, faces difficulty with social interaction and resists female sexual advances. The sense of narrative inertia is shattered when Lee travels back from Quincey to Manchester to receive news about Joe's death at the local hospital. In yet another flashback, the audience is informed that Lee's brother had been diagnosed with a serious heart condition, with a five to ten years life expectancy. These, for the moment, seem to constitute the tragic events of the film narrative: a middle-aged father precociously losing his life, his brother mourning this loss, sixteenyear-old Patrick, played by Lucas Hedges, being informed of his dad's passing away by Lee during hockey practice. Still, the viewer is in for a bigger surprise. When Lee is summoned to the local attorney's office to be informed of Joe's last wish that he be Patrick's guardian, the narrative, continually switching from the present to the past, foregrounds Lee's original trauma: his negligence causing his three children's death by fire at the family house. After the local authorities' ruling that he cannot be crucified for this horrible mistake, Lee attempts to kill himself in the police station and when this attempt fails, he decides to live in a solitary confinement which is interrupted, after years, by the lawyer's wake-up custody call. What follows in the second half of the film is the protagonist's agonizing struggle to face the challenge presented by deceased Joe's wish. During this phase, Lee temporarily moves to his brother's house in Manchester, where he lives with Patrick. After Joe's memorial service, a chance encounter with his estranged ex-wife, Randi, played by Michelle Williams, and a dream of his dead kids, Lee announces to Patrick his inability to settle in Manchester and his decision that the teenager be adopted by his father's best friend, George, and his wife. The film approaches its end with Joe's funeral, after which uncle and nephew are shown walking together and playing with a bouncing ball.

\section{Manchester by the Sea, Trauma Theory and Postmodernity}

The communion between the extradiegetic world, to which the audience pertains, and the intradiegetic world of the film's characters renders Manchester by the Sea a medium which can deliver an important statement about the pervasiveness of trauma in the postmodern age, an age which Cathy Caruth calls "catastrophic" (11 Explorations). The scholar approaches trauma as a mental wound, "a crisis of 
representation, of history and truth, and of narrative time” (Luckhurst 5). Indeed, the film's effort to represent unrepresentable human pain and insurmountable trauma exemplifies Caruth's approach and proclaims what Roger Luckhurst argues in The Trauma Question: popular culture [can] demonstrate not just the pervasiveness of trauma but also the reiteration of traumatic subjectivity in [a] different kind of register (15). The purpose which this different register can serve in the postmodern catastrophic age constitutes one of the main reasons why Manchester by the Sea deserves particular attention.

In Writing History, Writing Trauma, Dominic LaCapra states that "in any case it is purely misguided to see trauma as a purely psychological or individual phenomenon. It has crucial connections to social and political conditions and can only be understood and engaged with respect to them (xi). The film may indeed depict Lee's individual trauma but, as LaCapra contends, it also showcases how trauma can be molded by the forces -social, political, state- which forge the postmodern context of our lives and constitute one of the major loci of our chaotic, disoriented and unintelligibly dolorous human existence. The marked presence of state and social authorities in Manchester by the Sea contradicts with their inexistent support to the main character. What the medical, jurisdictional and police agents seem to do is, accordingly, to announce bad news at the hospital, to "understand" that Lee finds it hard to raise Patrick and, last, to the character's shock, to easily absolve him from the fire crime without providing practical, psychological and human support or guidance. As such, the body of state authorities and social service representatives in the film acts like a faceless, dehumanised agency of state and social power which almost parodies the severity of Lee's condition though the distanced and disorienting handling of the character's plight. Said reaction enhances Lee's unintelligibility of his own trauma and jeopardizes any hope for a better future. Following Caruth, Lee's wound is experienced as "an enigma of survival," and as a riddle of exemption from a crime paradoxically committed by one of its victims (Unclaimed 58). In The Condition of Postmodernity: An Enquiry into the Origins of Cultural Change, David Harvey elaborates on the impossibility to pursue a better future in the postmodern era and states that "postmodernism typically strips away the possibility [of a better future] by concentrating upon the schizophrenic circumstances induced by fragmentation and all those instabilities (including those of language) that prevent us even picturing coherently, let alone devising strategies to produce, some radically different future" (54). It is hard not to see the momentous place that Manchester by the Sea can hold as a mirror of the postmodern reality in which Lee's individual trauma bears the traits of a traumatic postmodern condition. Namely, his incapability to cater for Patrick and, hence, picture and produce a better, different future in a post-traumatic phase is linked to his fragmented use of language and to the staccato-style, significantly small amount of sentences which the protagonist utters during the narrative. Lee's utterance "I can't beat it" encapsulates in just five words the traumatic underpinnings of his final decision to reject Patrick's custody. The character's almost complete disavowal of language designates it as a medium which is functionally unable to articulate a story of loss, linking Harvey's observations on the problematics of language functionality and use to those expressed by trauma theorists. In "Truth and Testimony: The Process and the Struggle,” psychiatrist Dori Laub notes: "there are never enough words, or the 
right word, there is never enough time or the right time, and never enough listening or the right listening to articulate the story that cannot be fully captured in thought, memory and speech" (63, emphasis in original). Laub's linking the inadequacy of words to a problematic function of time creates another point of continuity between the postmodern and trauma theory. Elaborating on Frederic Jameson's approach to the postmodern individual as schizophrenic, Catherine Constable highlights that "the schizophrenic does not have a chronological sense of past, present, and future, and consequently lacks any sense of the self as a coherent identity that persists across time. It is this sense of being condemned to the perpetual present that Jameson takes to be emblematic of the postmodern condition" ("Postmodernism and Film" 43). Lee's child-death trauma has, likewise, condemned him to a state of traumatized limbo where Jameson's "perpetual present" is translated in a present experienced through its suspension and, almost, its absence. As we shall see, the film's use of flashbacks technically mirrors, confirms and enhances the loss of temporal continuity through a jeopardized, non-linear narrative temporal flow.

All in all, in Manchester by the Sea, postmodernism's celebration of depthlessness meets the vacuum which, according to trauma studies, occupies the human soul. The loss of a coherent sense of time corresponds to Lee's fragmented sense of a self that inhabits the narrative through ghostly presence and disorientation, expressed not only in terms of time and memory but also, as Harvey has it, in terms of a lost, inarticulable hope in the idea of progress and of a better, familial future. The above designate Manchester by the Sea as a most successful Hollywood antiblockbuster, one which privileges narrative over spectacle and places emphasis on the internal adventures and turmoil of the afflicted human psyche. ${ }^{2}$ In such wise, Lee's traumatic state can be viewed as a biggest metaphor of the postmodern traumatic condition which possibly affects the lives of the every-day anti-superheroes constituting the audience of the film, and the readers of this paper alike.

Lee's refusal to return to Manchester and take care of Patrick is indicative of a wound which seems to be unhealable, precisely because it bears the mark of grief and guilt at the same time. The contention of this paper is to examine the custody proposal as the main challenge of the narrative towards its main character, a challenge conditioned by the notion of trauma and circumscribed by the technical narrative device of the flashback, thereby initiating an interesting dialogue between the intradiegetic content and the form of the film. Joe's wish instigates feelings of grief and responsibility for Lee, a presumably failed parent who is asked to become his orphaned nephew's guardian. The question arising is whether Lee can ever awake from this traumatized state and, if he does, which the implications of said awakening are. The theoretical tools employed to uncover and explore the mechanics of this everdelayed awakening originate from trauma studies and psychoanalytic dream interpretation. More specifically, the present article, following Luckhurst, Pierre Janet and Lawrence Langer, will foreground the important role that flashback plays both in

\footnotetext{
${ }^{2}$ In the post-presentation discussion which took place at the conference where parts of this article have been initially presented, one of the questions coming from the audience concentrated, precisely, on the incongruence between the film's unhappiest thematics and the attention it attracted, hence becoming a financially big, not-happy ending, Hollywood success.
} 
the context of trauma theory and in the context of the film, where it acts as a catalyst, revealing the most note-worthy intradiegetic events. Secondly, this paper will delve into Caruth's analysis of the famous “Father, can't you see I am burning?” dream question in the context of the Freudian and Lacanian writings and, also, in the context of the film, where a similar question is asked. This will shed light on Lee's condition as a numbed individual who is sentenced to life in death by familial bereavement, hence by precisely the same circumstance which summons him back to life and demands that he assume and endure what Caruth calls the "ethical burden of survival."

\section{The Cinematic Flashback and Traumatic Time}

As mentioned above, the handling of time in Manchester by the Sea brilliantly reflects the mechanics of a traumatized person's mind and memory. In Holocaust Testimonies: The Ruins of Memory, L.L. Langer highlights that "trauma stops the chronological clock and fixes the moment permanently in memory and imagination, immune to the vicissitudes of time" (qtd. in Van der Kolk 177). Likewise, it seems that the chronological clock in Lee's mind is malfunctioning, the frozen fingers statically pointing to the tragic incident of the night of the burning. The form of the film mirrors this malfunction as linearity is undermined, governed by sweepingly significant flashbacks which seem to, accordingly, correspond to some of the most noteworthy events of the narrative. This filmic feature exalts, through temporal contrast and juxtaposition, the dysfunctional inertia of a present life and of a mind afflicted by events which have been impossible to either register, integrate or narrate.

Lee's visit to the lawyer and the latter's announcement of Joe's last wish trigger the compelling, multiple, fire scene flashbacks, which, in their turn, trigger and explain Lee's initial negative reaction to the custody proposal on the grounds of his child-death and parental responsibility trauma. Ambushed by Joe's will, Lee's refusal is elliptically articulated: "I do not understand," "I can’t," "I was just a back-up.” Sat against the lawyer, the character's iced facial expression, his empty but, yet, melancholic glance and the lack of emotional and physical energy communicated by a body just poured in the armchair, its right hand occasionally touching the head and then letting go, match the inexpressiveness of his limited linguistic production. After the lawyer states that he thought that Lee had spent some time in Manchester through the years, the dialogue is governed by long pauses. Said pauses are interruptingly suspended and assailed by what constitutes the so far unknown reason of Lee's refusal to become Patrick's custodian. Designating the flashback as the central device of visual narrative portrayal of trauma, Luckhurst argues that "cinema has been particularly effective at developing conventions in which the disordering of narrative presages the revelation of a traumatic secret, one which retrospectively reorders the fractured elements of plot into a new kind of story" (178). As such, the intermittent flashback scenes, accompanied only by suggestive music, visually articulate the unutterable, so far secret reason of the custody rejection. After a late night party with his friends, Lee runs out of beer and this leads to a life-changing mistake: on his way to the mini-market, he realizes that he has forgotten to put the screen on the living room's fireplace. In the longest, uninterrupted flashback, the camera captures Lee walking home from his back, then frames the burning house and, zooming out, moves, 
Trauma, Narrative and Responsibility

in revolving fashion, from frantic Randi's getting tranquilized by the fire fighters to the conglomeration of neighbours who are looking at the fire scene, their mesmerized faces lit up in red tones. The camera stops at Lee, then jumps to the burning house and, then, captures Lee from behind, framing him as a member of the bewildered mob. The dynamic form of the camera movements described above ostracize Lee to the position of an observant Other, an integral and yet fractured part of the scene: an insider-outsider. Namely, the protagonist is cast as a numbed, anonymous witness to the spectacle of his own family tragedy while the authorities remove his three children's bodies from the burning house scene, Randi infuriatedly dismissing his later attempts of consolation. During these scenes, the objective, impersonal camera angle communicates the hebetude of the protagonist's petrified face and body; overwhelmed by the unintelligibility of the spectacle, Lee still presses, against his chest, the minimart bag which, at that point, equals Pandora's box, marking the protagonist as both the witness and the perpetrator of the familial catastrophe. The fixity of Lee's facial and bodily position announce the standstill to which the fire crime will bring the character's life. ${ }^{3}$ This freezing effect is redoubled by the regressing sequences which are, according to Luckhurst, "the cinema's rendition of the frozen moment of the traumatic impact ... flash[ing] back insistently in the present because the image cannot yet or perhaps ever be narrativized as past” or, I would add, experienced (180). Pierre Janet makes a similar observation on the limits of liquidation and recital in view of trauma: "a situation has not been satisfactorily liquidated until we have achieved an inward reaction through the words we address to ourselves, through the organization of the recital of the event to others and to ourselves" (qtd in Van der Kolk 171). In other terms, Lonergan's strategic employment of silence and narrative anachrony at this point serves to illustrate Lee's incapability to recite the events and, by extension, the reason of the guardianship rejection to the lawyer. This further showcases, following Janet, that the traumatic event here cannot yet be addressed as it has not so far been liquidated and reconstructed into a narrative by the traumatized.

\section{Dreaming, Awakening, Responsibility and Survival}

I have characterized above the lawyer's call 'a wake-up call' and it is now the moment for attention to be focused on the pivotal role that the issues of dreaming and awakening play in the narrative, in terms of Lee's addressing his trauma. Said wakeup call triggers the action in the film- if there is any action at all for action is usually associated with change, it is pregnant with progress. In Manchester by the Sea's case, instead, whatever happens is so closely associated with the past to the point of creating a fixated loop from which Lee seems to be unwilling, because of his guilt, or unable, because of his trauma, to escape. Even so, Joe's death and the lawyer's call force Lee to physically travel back to Manchester, namely to the site of his original trauma.

\footnotetext{
${ }^{3}$ Lee's silence and life stagnancy are epitomized in his living in an almost empty, small basement apartment, the decoration of which is dominated by three frames carrying his children's photos, a characteristic which turns the apartment into a mausoleum where Lee's life and memory are entombed.
} 
Confronted with the lawyer's proposition and with Patrick's begging plea to rethink about the matter (let us remember the irony of the very first scene when the kid 'rejects' his uncle), Lee's sense of failure as a parent is blended with a new sense of paralysed incapacity to assume the very same kind of parental responsibility in the present and future.

The scene of Lee's chance encounter with his ex-wife, Randi, who now has a new husband and a baby, serves to redouble Lee's sense of loss and guilt, on the one hand, and to highlight his numbing, on the other. ${ }^{4}$ The characters meet by chance at the street and engage in a short but meaningful dialogue with charged emotional undertones. As we learn from their dialogue, Randi and Lee are estranged to the point that Lee repeatedly rejects is ex-wife's proposals to have lunch. In his interview with Caruth, Robert Jay Lifton designates separation as a death equivalent, which turns the couple's divorce and estrangement into both a consequence and a replication of their child-death trauma (136). Coding, in terms of bodily movement and vocal intonation, also highlights the distance separating the two spouses: Randi's face, mapped by tears, her sobbing voice and quivering body contrast with almost immobile Lee's, steady, barren voice. As in answer to Randi's wailing pleading “you can't just die” and to her admitting that she should burn in hell for having accused him of negligence, Lee's blank glance continually evades both focus and confrontation, restlessly looming in the space separating him from Randi. The emptiness of his gaze matches the emotional void communicated in the unfinished, incomplete sentences starting with "I, I, I can't" and "I'm not, I'm not, I'm not [gonna die]." His uttering the full sentence "You don't understand. There's nothing, there's nothing there" coincides with the unique instance when Lee fixes his gaze into Randi’s eyes. Right after this, he leaves. The phrase stands as the first diegetic linguistic confirmation of the blankness governing the character's psyche. Articulated in his effort to end and escape the dolorous confrontation with Randi and with his past, Lee's "nothing there" is symptomatic of his numbing which Lifton defines as "the experience of a deceased or absent feeling," tantamount to "a cessation of feeling" altogether $(134,136)$.

Much like the lawyer's call, the encounter with Randi triggers the unregistered, 'unlived' memories of a haunting past. Lee's remorseful feeling that he has survived his children's burning and Joe's, hence a caring parent's, death is blended with grief. Almost as a result of said psychological state, the character experiences a second, more literal awakening after dreaming of his two daughters sitting on the couch with him, the eldest one suggestively asking, "Daddy, can't you see we are burning?” The question echoes the one from Freud's The Interpretation of Dreams. These two awakenings, the lawyer's wake-up call and the one after the quasi-Freudian dream, bring Lee against what Cathy Caruth calls the "ethical burden of survival" in Unclaimed Experience: Trauma, Narrative, and History. In the chapter entitled "Traumatic Awakenings" Caruth offers a comprehensive comparative analysis of Freud and Lacan's elaboration of the almost same question articulated in another father's dream of his child burning. The scholar examines the dream question with

\footnotetext{
${ }^{4}$ This heart-breaking scene received special critical attention, with both actors praised for their outstanding performance.
} 
relation to the mechanics, significance and implications of awakening from a traumatizing dream and from a traumatizing reality alike.

The dream belongs to a father who had just lost his child to feverish illness and decides to get some rest in the next room while an old man has been appointed to watch over the dead child's body surrounded by tall funeral candles. At some point, the father dreams that "his child was standing beside his bed, caught him by the arm and whispered to him reproachfully: 'Father, don't you see I'm burning?"' (Freud 513, emphasis in original). The father wakes up to the shock of reality matching the content of this dream: a candle has fallen and the dead child's wrapping and one of the arms are on fire, the old man having fallen asleep next to the kid. As Caruth points out, Freud first situates the dream within the theory of wish-fulfillment as the dead child is brought back to life via the father's prolonging his sleep by one moment (95). Still, the scholar goes on to highlight Freud's later remarks on the dream: apart from the father's wish to see the child alive once more, the dream itself springs from "the desire of consciousness as such not to wake up" "desir[ing] somehow its own suspension" $(97,6)$. A significant question, thus arises, "What does it mean to sleep? And what does it mean to wish to sleep?” (97, emphasis in original).

In his seminar “Tuché and Automaton,” Jacques Lacan returns to the burning child dream. The psychoanalyst wonders "how can the dream, the bearer of the subject's desire, produce that which makes the trauma emerge repeatedly" (55). This concern leads to his remark that hardly can the dream under discussion correspond to the realization of a desire for the content of the dream is itself traumatic (57). Hence, Lacan posits that, rather than emerging from sleep, the dream emerges from reality itself for it so near, after all, to the physical reality of the fire which is surrounding it. According to Lacan, then, it is not in sleeping that one needs to look for the meaning of this dream, but in reality itself and hence, in awakening: "is it not the dream essentially, one might say, an act of homage to the missed reality-the reality that can no longer produce itself except by repeating itself endlessly, in some never attained awakening?"(58). As Caruth stresses, in this paradoxical awakening against the wishes of consciousness the dreamer confronts the traumatic reality from which he cannot escape, the dream becoming not a function of sleep but a function of awakening, the question then, being What does it mean to awaken to one's trauma (99, emphasis in original). Caruth, commenting on Lacan, proposes that "awakening constitutes the site of trauma, the trauma of both the necessity and incapability to respond to the beloved person's death" as the father awakens to his previous failure to see in time and witness the child's dying as it occurred (100).

Hardly can one not see the parallel between Carruth's interpretation and Lee's case, where the dream, faithful to the film's emphasis on anachrony, stands as a flashback-like intrusion of the past into the present. The physical reality to which Lee awakens after his dream is the burning coming a pan catching fire in the kitchen. The missed reality to which he awakens is not only the missed chance to prevent the catastrophe due to his late arrival at the site of his own parental crime but, most importantly, his traumatic witnessing of his children's burning, which blended the physical necessity to react with the emotional incapability to respond and process the event at all. Lacan's endless repetition of the traumatic reality is crystallized, in Lee's case, in his inability to try to fight his trauma, in contrast to his ex-wife. A noteworthy 
difference between the father and Lee's dream is the temporal occurrence of the offspring burning. In Lee's case, the child burning precedes the dream, by years. This serves to accentuate Lee's incapability and denial to come to terms with his wound long after the incident, something which is also proved by his answer to his daughter in the dream: "No, honey, you are not burning." Lee constantly swims, a human automaton, in that limbo of unconsciousness which Lacan situates between perception and consciousness, "a non-temporal locus, the idea of another locality, another space, another scene," hence the site of trauma par excellence (56).

So, Lee awakens from the dream to a nightmarish reality, the next question now being: can he ever awaken from the nightmarish reality which engulfs the reality of the dream? And what about the role that the dead daughter's address play in the context of this awakening? After all, half of the dream consists of these words. An active, powerful agency is hidden behind the daughter's address urging Lee, to borrow Caruth's words, to face the "ethical burden of survival" which, in his case, means to awaken, to survive to tell the story of the burning and to subsequently depart from his own trauma at the command of the burning child[ren] (106). It is, namely, an appeal for the tragic event to be liquidated, to be turned into the narrative which was impossible to recite some time ago at the lawyer's office. The daughter's address communicates the imperative, to quote Caruth, that "the words are passed on as an act that does not precisely awaken the self but, rather, passes the awakening on to others" (107, emphasis in original). This passing on of words plays a major role in the film. Joe passes on his parental responsibility to his brother, the lawyer passes on Joe's last wish to Lee. Inasmuch as Lee is asked to tell the story of the burning, he is also asked to be his nephew's guardian. Awakening from the dream means facing the traumatic reality; responding to the daughter's words means facing the ethical burden of survival. In such a context, responsibility can assume a two-fold meaning and transubstantiate from responsibility for the children's death to responsibility for building that unattainable, better future life for Patrick, the recipient of the effect of Lee's awakening. It is, indeed, not accidental that Patrick is diegetically associated with action and motion: from hockey-practice to school-band singing and from visiting his mother's home to spending time with his girlfriends, Patrick is a symbol of energetic and active copying with mourning and parental loss through juvenile, recreational activities. As such, the pattern of the teenager's behavior does not only stand as a contrasting motif to Lee's static copying mechanisms but, also, renders the nephew an ideal, 'prepared' recipient of Lee's awakening.

Yet, as Manchester by the Sea shows, Lee is not yet disposed to fend for Patrick and depart from his trauma by subversively returning to the traumatizing locus of Manchester. The incomprehensibility of the character's wound, crystallized in socio-state reaction and represented in the protagonist's numbed psychological state, is one of the main reasons contributing to this decision. Some days prior to Joe's burial (his body had been kept in the refrigerator until spring) Lee announces to Patrick that he will be adopted by his father's best friend and his wife. Patrick responds to his uncle's decision to move to Boston and leave him behind in tears: "Why can't you stay?” Lee’s reply is revelatory of his condition: "I can't beat it," he answers twice, "I’m sorry." 
Trauma, Narrative and Responsibility

Although trauma still possesses Lee, the character seems to be open to start facing the ethical burden of survival at the end of the film, right after Joe's funeral. Walking home together, Lee and Patrick play with a bouncing ball. The ball's nature and movements function as an overarching metaphor and recapitulation of Lee's story. At first, an 'agency' needs to hit the ball for it to escape inertia, much like Lee's daughter and brother knock on the protagonist's trauma and shake the stagnant waters of his life by inviting him to awaken from his wound. Back to the ball, after someone hits it against a surface, it starts moving and keeps returning back, exactly like death is one of life's recurrent, returning motifs, responsibility for the beloved left behind inevitably changing hands, like the bouncing ball in the film does. So, while casually taking turns and playing with the ball, Lee announces that his new home in Boston will have a separate room so that Patrick can visit or sleep over while looking for colleges in that same city. It is the first time in the narrative that Lee welcomes the idea of breaking his solitary confinement and of including another person in his future life plans. The idea of companionship is tacitly celebrated in the last scene of a film ending where it started, the cycle resonant of the bouncing ball's repetitive movement, of trauma's recurrent nature: two men sit on Claudia Marie, in Manchester, fishing together in one another's silent company.

\section{Works Cited:}

Caruth, Cathy. Unclaimed Experience: Trauma, Narrative, and History. Baltimore: John Hopkins UP, 1996. Print.

---, “Introduction.” Trauma: Explorations in Memory. Ed. Cathy Caruth. Baltimore: John Hopkins UP, 1995. 3-12. Print.

---, “An Interview with Robert Jay Lifton.” Trauma: Explorations in Memory. Ed. Cathy Caruth. Baltimore: John Hopkins UP, 1995. 128-150. Print.

Constable, Catherine. "Postmodernism and Film." The Cambridge Companion to Postmodernism. Ed. Steven Connor. Cambridge: Cambridge UP, 2004. 4361. Print.

Freud, Sigmund. The Interpretation of Dreams. Trans., Ed. James Strachey. New York: Basic Books, 2010. Print.

Harvey, David. The Condition of Postmodernity: An Enquiry into the Origins of Cultural Change. Cambridge MA: Blackwell, 1990. Print.

Lacan, Jacques. The Seminar of Jacques Lacan: Book XI The Four Fundamental Concepts of Psychoanalysis. Trans. Alan Sheridan. Ed. Jacques-Allain Miller. New York: Norton, 1998. Print.

LaCapra, Dominic. Writing History, Writing Trauma. Baltimore: John Hopkins UP, 2014. Print.

Laub, Dori. “Truth and Testimony: The Process and the Struggle." Trauma: Explorations in Memory. Ed. Cathy Caruth. Baltimore: John Hopkins UP, 1995. 61-75. Print.

Luckhurst, Roger. The Trauma Question. London: Routledge, 2008. Print.

Manchester by the Sea. Dir. Kenneth Lonergan. By Kenneth Lonergan. Prod. Matt Damon. Perf. Casey Affleck, Michelle Williams, Kyle Chandler, and Lucas Hedges. Amazon Studios, 2016. 
Trauma, Narrative and Responsibility

Van Der Kolk, Bessel A. and Onno Van der Hart. "The Intrusive Past: The Flexibility of Memory and the Engraving of Trauma." Trauma: Explorations in Memory. Ed. Cathy Caruth. Baltimore: John Hopkins UP, 1995. 158-82. Print. 